\title{
Learning from failed policy mobilities: Contradictions, resistances and unintended outcomes in the transfer of "Business Improvement Districts" to Germany
}

European Urban and Regional Studies 2017, Vol. 24(I) 35-49

(c) The Author(s) 2015

Reprints and permissions: sagepub.co.uk/journalsPermissions.nav DOI: I0.1 I77/09697764|5596797 journals.sagepub.com/home/eur

@SAGE

\section{Christian Stein}

Goethe-University Frankfurt, Germany

\section{Boris Michel}

Friedrich-Alexander University Erlangen-Nürnberg, Germany

\section{Georg Glasze}

Friedrich-Alexander University Erlangen-Nürnberg, Germany

\section{Robert Pütz}

Goethe-University Frankfurt, Germany

\begin{abstract}
This paper contributes to the debates on policy mobilities by examining Business Improvement Districts (BIDs) in Germany as examples of contested, failed and unfinished travelling policies. Recent debates on policy mobilities opened a fruitful discussion on how policies are transferred from one place to another and the complex processes that rework places and policies in heterogeneous ways. While we are sympathetic to this literature, there are theoretical and empirical gaps to be addressed. It is frequently stated that processes around the transfer and grounding of policies are complex, and that outcomes are far from secure. However, the empirical focus in most cases is on transfers that are more or less "successful", or at least portrayed as being successful by their advocates. In contrast to this "success bias" in research and public discourse, we argue that it is helpful to focus more closely on failures, resistances and contradictions. Judging from work on the transfer of BIDs - an almost classical example of successfully mobilized urban policies - we argue that it is helpful to reflect on unfinished policy mobilities, that is, the failure of mobilized urban policies.
\end{abstract}

\section{Keywords}

Business Improvement Districts, Germany, neoliberalism, policy mobilities, urban development

\section{Introduction}

Without falling into the pitfalls of classical literature on policy transfer, recent debates on mobile policy opened up a wide-ranging and fruitful discussion on

\section{Corresponding author:}

Christian Stein, Department of Human Geography, Goethe-

University Frankfurt, Theodor-W.-Adorno-Platz 6, D-60629

Frankfurt am Main, Germany.

Email: stein@geo.uni-frankfurt.de 
how policies are transferred from one place to another (e.g. McCann and Ward, 2011; Peck, 2011). It was convincingly argued that classical accounts of the process, which mostly emerged from political science, were not able to understand the transfer of policies as a complex process that reworks places and policies in heterogeneous ways (McCann and Ward, 2012b). While we are sympathetic to this literature, there are theoretical and empirical gaps to be addressed.

Underlying most of the discussions is the notion that policies are increasingly mobile. Policies have without doubt been on the move for a long time. While the social sciences have long addressed issues of how knowledge and practices are diffused and exchanged, policy mobility has changed in quality and grown in quantity in recent years. If one looks at policies of urban governance, for example, there are a wide range of tactics, policies and strategies for governing urban space that have been mobilized around the globe. These include "zero-tolerance", urban social policies or more neoliberal inspired forms of governing urban spaces, such as Business Improvement Districts (BIDs).

City managers, it is argued (McCann and Ward, 2010), are increasingly forced to scan the globe for new and better strategies to cope with their local problems. Places like New York City in the mid1990s became emblems of "successful" cities that reshaped their fate by applying tough and energetic measures and discarding old (often statist) modes of "getting things done". These places have thereby become important and powerful icons of highly acclaimed, international "best practices".

While it is frequently stated that the processes of transfer and grounding of policies are complex and the outcomes far from secure (Peyroux et al., 2012; Robinson, 2011), the empirical focus in most cases is on transfers that are either more or less "successful" (Cook and Ward, 2012; Didier et al., 2012; Ward, 2006) or at least portrayed as such by their advocates (Binger, 2010; Brenner, 2010). Failure and unsuccessful transfers are mentioned only rarely (for a notable exception, see Perrons and Posocco, 2009, and the corresponding special issue on "Globalizing Failures") and hardly elaborated on in research on mobile policies, despite very recent case studies regarding immobile sustainability policies by Carr (2013), McLean and Borén (2014) and Müller (2015) and early calls by Dolowitz and Marsh (2000) to explore the relationship between policy success and failure.

In contrast to this "success bias" in the research and public discourse, we argue that it is necessary to examine failure, resistance and contradictions. By these terms we refer to a variety of moments in which the expected outcomes of a policy and its mobilization do not materialize. Failure, as Perrons and Posocco (2009: 132) point out, "exceeds the narrow ascription of policy malfunction or technical ineffectiveness and provides instead an opportunity to probe a plurality of situated understandings and interpretations". By focusing on breaks, cuts, stoppages and detours we want to emphasize the contingencies and particularly the contested character - of seemingly hegemonic policy patterns.

In this paper we present findings from a comparative research project on BIDs in Germany that provide a starting point for thinking about the role of models that are framed as successful within contemporary debates on mobile urbanism. Judging from work on the transfer of BIDs - an almost classical example of mobilized urban policies that is often seen as paradigmatic of neoliberal urban governance - we argue that much can be learned by reflecting on the failure of mobilized urban policies and attempts to globalize neoliberal modes of urban governance.

\section{Mobile policies and mobile urbanism}

The planning and governing of cities has always relied to some degree on knowledge of practices in other cities. Research on policy transfer has a long history in the social sciences that extends back to the very foundation of the discipline. Policy mobility has changed in quality and grown in quantity in recent years; it seems reasonable to speak of a specific policy mobility that coincides with the height of neoliberalism. It is thus not surprising that recent literature on policy mobilities largely analyses processes of neoliberal urbanism. However, to understand current debates on mobile urbanism and mobile policies, it seems important to take into account more recent 
literature on policy transfer, mainly from political sciences, in which questions of transfer, diffusion, lesson-learning and policy convergence are of some importance (e.g. Dolowitz and Marsh, 1996; James and Lodge, 2003; Wolman, 1992). This research focuses on processes through which knowledge of policies, institutional settings and practices is transferred from one spatial and temporal context to another. Reasons for such a transfer might be the definition of common problems, processes of learning, the power of hegemonic concepts or coercion. Generally, political science research on policy transfer focuses on the transfer between nation states; states and state agencies are thus treated as the most important actors (with respect to Business Improvement Districts see Hoyt 2006, 2008).

From the perspective of poststructuralist human geography, this literature is of limited use: it underestimates local trajectories, is often based on notions of convergence and focuses on intentional and formal actors. Framing policy transfer as a rationalistic process, this literature is somewhat blind to the content of said transferred policy and its mutation on the move and in the different contexts (for a detailed critique, see McCann and Ward, 2012b).

Recent work on policy mobilities (Peck, 2011; McCann and Ward, 2011) provides greater purchase for understanding the increasing globalization of ideas and policies in urban governance, because it views policy transfer from a more dynamic and more political vantage point that takes into account recent discussions on the complex and diverse productions of spaces and places. Drawing on a language of mobility and fluidity, this work shows that policies do not just move from place A to place B but are always embedded within complex and power-laden circulation patterns of knowledge that are intrinsically political and constantly rework these travelling concepts (Künkel, 2015). Following Peck and Theodore (2010), these approaches can be characterized by their rejection of rationalist explanations and a focus on the contested and political nature of transfer. Policies seldom travel as complete packages but "move in bits and pieces", picked and changed to suit local contexts and the interests of different actors. Thus, policies are constantly reassembled in often complex and contradictory ways.
With regards to the geography of policy transfer, Peck and Theodore (2010: 170) argue that

...[t]he spatiality of policymaking is not flattened into some almost-featureless and inert plane or transaction space, marked only with jurisdictional boundaries, across which transfers occur, but in terms of a threedimensional mosaic of increasingly reflexive forms of governance, shaped by multi-directional forms of cross-scalar and interlocal policy mobility.

This notion that the urban is constantly reassembled - while posing the danger of underplaying the role or even denying the existence of structural forces - creates a lens through which to examine the transfer of policies of urban governance in a much more contested and thus more political way (Collier and Ong, 2005; Farías and Bender, 2010; McCann and Ward, 2011; McFarlane, 2011). Much empirical work in this field is embedded in a wider field of research on neoliberal urbanism or neoliberal modes of urban governance and explicitly follows policies across national and scalar boundaries. Case studies are drawn from a wide range of urban policies. There is work on the transfer of drug policies from European cities to Vancouver (McCann, 2008), on BIDs (Cook, 2008; Cook and Ward, 2012; Ward, 2006, 2007), on creative industries policies (Prince, 2010), on migration policies (Pütz and Rodatz, 2013) and more general elaborations on "third way policy transfer" (Peck and Theodore, 2001). A special focus is less on the policy elites but on the "middling technocrats", on rather mundane practices of transfer and the knowledge of experts (Allen and Cochrane, 2007; Guggenheim and Söderström, 2010; Peck and Theodore, 2010; Robinson, 2011).

These approaches require new ways of researching policy transfer. Rather vague notions of how to approach these changing relational processes of policy transfer dominated earlier contributions to this literature; recently, there has been increasing interest in methodological questions. Researchers such as Cochrane and Ward (2012: 7) have called for

...reflect[ion] on the ways in which a focus on these issues may also require the mobilization of particular sets of methods, demanding a step beyond the relative comfort zone of case studies and semi structured 
interviews, however necessary they may be as part of the process.

Most contributors would argue that ethnographic methods should be used to study these new and complex forms of mobility and their grounding in particular places. According to Roy (2012: 34), "the study of policy mobilities necessarily leads us to "ethnographic circulations"". This new mode of ethnographic research, it is argued, has to address mobile policies in multi-sited, mobile and global approaches that "follow the policy" (Peck and Theodore, 2012), but also understand the grounding of these policies in complex local assemblages, sites and situations (McCann and Ward, 2012a). While we are sympathetic to both the new literature on mobile policies and this call for ethnographic methods and multi-sited approaches, we argue that the current research is dominated by a problematic bias for (from a practitioner's perspective) "successful" transfers and models.

\section{Success bias in analysing Business Improvement District mobilities}

Following from this literature review, we argue that there is a strong focus on policies that are perceived as having been successfully transferred and mobilized. Moreover, the literature leans strongly towards researching places that are, from a policies entrepreneur's viewpoint, regarded as successful - as places other places strive to learn from. This means that much research focuses on a small number of flagship projects in a very limited number of cities, without taking into consideration either minor, much less visible, projects or the uncounted failed attempts in places that do not garner public attention. While we do not attempt to downplay the real and symbolic power of places represented as successful in terms of their impact upon policies in other places, we argue that this focus limits our understanding and that there is a lot to learn from failure.

A focus on mobility, methods of "following the policy" and "studying through" are often applied in ways that run the risk of unintentionally reifying mobile (and often neoliberal) urban policies as successful. Shore and Wright (1997: 14), for example, argue for "studying through" the processes of policymaking and point out that tracing "the ways in which power creates webs and relations between actors, institutions and discourses across time and space" is crucial to understanding contemporary processes of interconnected policy formation. According to Wedel et al. (2005: 39f.), "following the source of a policy - its discourses, prescriptions, and programs - through to those affected by the policy" is an effective way to unfold processes of inter-urban policymaking. However, it entails the implicit risk of adjusting the bias towards repeatedly telling "stories of success" (Schwedes, 2012).

In contrast to this, focusing on the failure of mobile policies helps prevent us from overemphasizing inter-urban policy pathways over local path dependencies and resilience. Focusing on failure allows us to view policy "mobility" as a metaphor for interconnected global-local processes, rather than as mobility in the literal sense. It also allows us to frame mobile policies as a contested, fractured and often inherently contradictory process marked by unpredictable outcomes.

One could argue that the focus to date on successful transfers and "successful" places results from an uncritical adoption of the perspective of the agents of transfer, who popularize those transfers in conference papers, presentations and publications. From this perspective, the literature seems to take those involved in the transfer and its promotion at their word and use that, in an uncritical way, as an entry point for their research. Places that did not produce outcomes that are perceived as successful and noteworthy are thus systematically overlooked (Michel, 2013b). Moreover, the very notion of mobile policy and policy transfer implies some form of success. Even though the current literature on mobile policies highlights the often contested and contradictory process of policy mobilities, there is little room for failure within this concept.

Finally, there are methodical problems with doing research on things that are characterized by their absence. Especially with ethnographic methods and a focus on emergence and assemblages, it is difficult to engage in research on disappearance and disassemblages. Thus, shifting the focus of research onto failing transfers would require different research methods. 
This bias towards "successful" stories of transfer and implementation holds true for BID policies and research on those policies. In research and literature on BIDs the focus is mostly on BIDs in a very limited number of places. Most of these BIDs stand out, in terms of their visibility, functions and disposable resources. The BID model emerged in Canada in the late 1960s; however, apart from anecdotal references to the businessman who singlehandedly started the idea as a means of revitalizing his neighbourhood in Toronto, little attention is paid to the early phase of BID history. BIDs became a significant issue only in the early 1990s. Critical scholars and advocates of BIDs in these later years focused heavily on New York City. Iconic places, such as Times Square, Downtown Manhattan, Grand Central and Bryant Park, became major points of reference. BIDs were heavily debated as either key agents of the "revanchist" city and the end of public space (Glasze, 2001; Katz, 2001; Smith, 1996) or as agents for New York's highly acclaimed renaissance (Kelling, 2009; Mac Donald, 1996). Judging from the literature on BIDs in Germany, these places are the ones most frequently referred to.

Since the 1990s, the focus has broadened somewhat, and places like the Center City District in Philadelphia have become a major point of reference. This BID is not just one of the largest, but it also performs some of the most complex tasks of any BID. Its CEO, Paul Levy, is also a key figure in the international transfer of BIDs. He has presented at international meetings such as the IDA (International Downtown Association) World Congress in London 2010 and the German BID Congress in 2010 in Bochum, published oft-cited papers on BIDs in the US (Levy, 2001) and - like New York's Daniel Biederman in the 1990s - is often referred to as a "BID guru" (McCann and Ward, 2010: 178).

Since the early 2000s a number of more modest BIDs, such as "125th Street" in Harlem and "Dumbo" in Brooklyn, have drawn the attention of researchers. While the early debate centred on their association with harsh policies and the new policing of urban space in Giuliani's New York, places like "Dumbo" have become icons of a new wave of gentrification and the emergence of the "creative class". In 2003, before the first BID law in Germany was put in place, the German Chamber of Commerce organized a first study trip to examine and learn from BIDs like "Bryant Park", "Dumbo" and the "Alliance for Downtown Manhattan". This focus on "successful" showcases can be observed in the case of BID advocates, such as agents of international transfer and local practitioners. For example, hardly any article on the introduction of BIDs in Germany fails to mention the "Neue Wall" BID in Hamburg as a shining example of a broad movement that emerged from a number of famous models on the east coast of the USA (Bundesvereinigung City- und Stadtmarketing e.V. (BCSD), 2007; Eick, 2012; Rothmann, 2008).

\section{Towards researching failing mobile policies}

In the main part of this paper we address failing mobile policies by presenting findings and questions from an ongoing research project on BIDs in Germany. In this project, we encountered numerous diverse examples of BID failure, the disappearance of projects and the fading away of voices promoting urban property owner associations. Many attempts to implement BIDs led to instances in which BIDs got stuck. A broad range of initiatives never achieved the status of a legally enacted BID (Michel, 2013b; Pütz, 2012; Schwedes, 2012). While BIDs are a prime example of mobile policies, and while a number of studies in the field of policy mobilities highlight BIDs as showcases for mobilized forms of neoliberal urban governance, we argue that a success bias in the literature limits our understanding of these processes. Moreover, while recent literature on mobile policies explicitly highlights contingencies, variegation and ambivalence, the focus on "successful" projects obscures the fact that transfers often fail. By not looking at these cases in more detail and disregarding them as unimportant, the success stories of the advocates of transfer are reinforced.

While it is hard to find conclusive quantitative evidence on the percentage of failing BIDs, failure appears to be a regular outcome. Besides the question of how rampant such fractured processes of BIDs are in general, it is more important to understand how and why policies often associated with 
seemingly hegemonic discourses in the field of neoliberal urbanism are highly contested.

By elaborating on moments of failure we show that the establishment of BIDs failed in cases where (1) the discursive constitution of an urban crisis that could have legitimized BIDs as the appropriate means of solving the crisis failed or (2) a broad crisis discourse existed but there was no consensus that BIDs would solve the crisis. Our empirical studies of BIDs in Germany thus indicate that - more often than not - the assumed pro-BID coalition of actors such as property owners, local capital and neoliberal local politicians is very fragile, contradictory or simply does not exist.

\section{Learning from failed mobilizations - the bumpy ride of Business Improvement Districts to Germany}

From the perspective of their advocates, BIDs in Germany are mostly portrayed as successful models for revitalizing city centres, and their transfer to the German context is portrayed as a relatively simple and straightforward endeavour. In contrast to this portrayal, our research on BIDs in Germany uncovered numerous cases in which the model and its transfer were far from successful (Pütz et al., 2013).

While the first legally enacted BID was established in the City of Hamburg in 2005, initial discussions predate its establishment by several years. In 1998, the North-Rhine Westphalian Ministry of Work, Social Integration, Urban Development, Culture and Sport (Ministerium fürArbeit, Soziales und Stadtentwicklung, Kultur und Sport des Landes Nordrhein-Westfalen) organized a conference on urban entertainment centres and private urban planning; at this conference, a talk on BIDs in the USA sparked a debate on the matter in Germany (Ministerium für Arbeit, Soziales und Stadtentwicklung, Kultur und Sport des Landes Nordrhein-Westfalen (MASSKS), 1999). For the broader community of property owners, government agencies and chambers of commerce, BIDs became a subject of interest following the publication of a study commissioned by the Department of State of Urban Development and Housing in North-Rhine Westphalia (Bloem and Bock, 2001). This study was the first survey on whether BIDs could be transferred to Germany and whether or not there would be political and constitutional constraints. The government of North-Rhine Westphalia, which was a stronghold of German Social Democrats until 2005, initially decided against the BID model. It favoured a voluntary model over the compulsory BID model that would force property owners to join a BID. In the end, a BID scheme was introduced in North-Rhine Westphalia a couple of years later, but only after the first BIDs had been launched successfully in other federal states and the Christian Democratic Union (CDU) had established a majority government for the first time in 40 years. ${ }^{1}$ By early 2015, only four BIDs had been established in North-Rhine Westphalia; the first one established abandoned its mandate and failed after only a few months. The vast majority of property owner associations in North-Rhine Westphalia are still running on a voluntary basis.

In 2004, the city-state of Hamburg was the first federal state to pass a BID law and, hence, the first German BID was established there. This is also why Hamburg's BID law led the way and represents the blueprint for all later BID laws in other federal states (Michel and Stein, 2015: 86). So even if the planning law system in Germany requires BID legislation to be passed at the level of the federal states, BID laws vary just slightly. In general they require 15 per cent of the property owners, holding at least 15 per cent of the given area, to actively support the implementation of a BID. If less than a third of the owners reject the plan, the city installs the BID and the steering committee - a committee open to all property owners. The steering committee then commissions a body to execute the BID's tasks and duties. The BIDs are financed by a tax based on property values, which is imposed by the respective local state in addition to real estate taxes from all property owners within a BID area.

By early 2015, eight out of the 16 federal states had passed BID legislation, and 31 BIDs had been initiated in 15 cities and municipalities. Eleven of them have already phased out, and nine are continuing in a second phase. More than a third of these BIDs are located within Hamburg's city limits.

As we have argued elsewhere (Michel, 2013a; Michel and Stein, 2015), Hamburg's success as Germany's BID capital is due to its extraordinary 
urban regime. The relatively smooth introduction of BIDs there can be attributed to the city's highly supportive local government, a former mayor who made BIDs a priority, a powerful and proactive chamber of commerce, a discourse portraying Hamburg as a city of Hanseatic merchant-traders and a growing economy and city.

The exceptional nature of Hamburg's success with BIDs becomes especially apparent when one compares Hamburg with other regions in Germany. According to the German Chamber of Commerce in the federal state of Saarland, which regularly published a report on BIDs, three out of four attempts to establish BIDs in that region failed. In the federal state of Schleswig-Holstein, only two out of six BIDs initiated in 2007 materialized. Overall, not much progress has been made. From 2005 to 2013, BID laws were established in fewer than half of Germany's federal states. As we have already mentioned, only six out of the 16 federal states have BID legislation in place. With the exception of the federal state of Saxony, little progress has been made since $2008 .^{2}$ From this point of view, the notion of a coherent neoliberal hegemony - for which BIDs often serve as a prime example - becomes questionable. By focusing on processes of establishing BIDs in the federal state of Hesse, we now turn to more "ordinary cities" (Robinson, 2006) as cases for analysing heterogeneous and fractured mobilizations of BIDs.

In 2006, Hesse passed the Law to Strengthen Inner-City Retail Districts (Gesetz zur Stärkung von innerstädtischen Geschäftsquartieren) and thereby became the second German state to introduce BID legislation. Later that year, the first BID was launched in the medium-sized town of Giessen (pop. 80,000), where just a few months later, in early 2007, three more BIDs were established. Ideas and plans to establish BIDs in other and more major cities such as Frankfurt quickly emerged. This development was interpreted as indication of a dynamic process and a "noticeable success of the BID idea" (Säfke, 2007: 12; all translations by the authors). However, more than five years later there is little evidence of a dynamic expansion. In late 2012, there were still only four BIDs in Hesse (see Figure 1). While a new BID was established in the city of Offenbach, one BID in the town of Baunatal and one in the city of Giessen ended their term

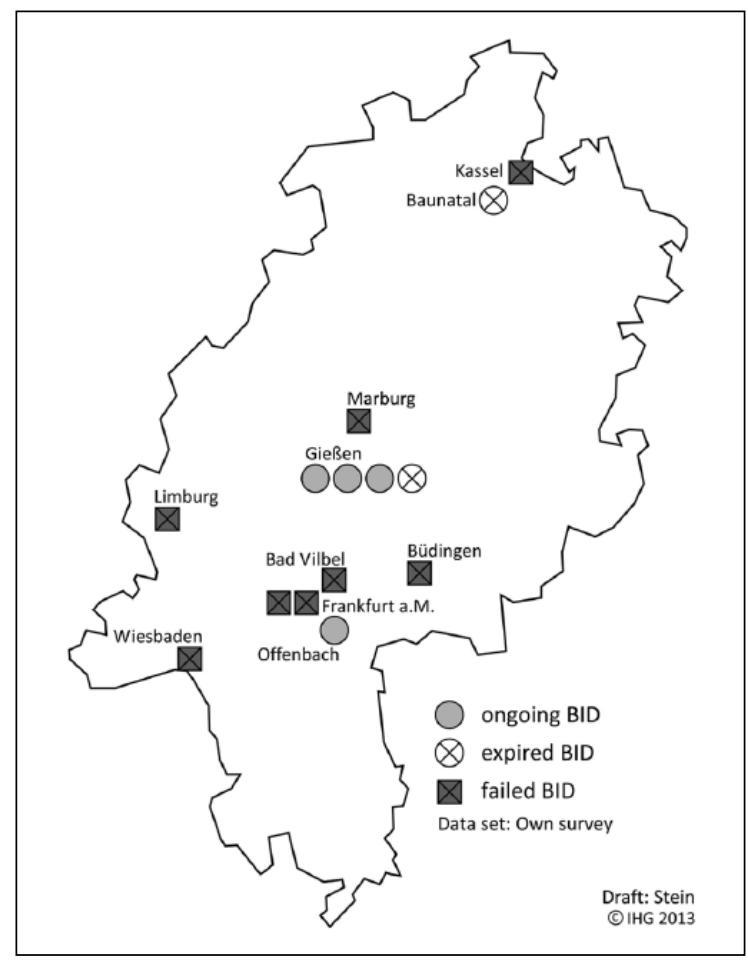

Figure I. Business Improvement Districts (BID) and failing BID initiatives in Hesse.

without renewal. Hence, one of the most active agents in Hesse, the chamber of commerce's representative for BIDs in Offenbach, emphasized that "after five years the experience is disillusioning" (Köhler, 2010; translation by the authors).

At the same time, there have been plans, attempts and debates in a number of places in Hesse. Besides those BIDs mentioned above, initiatives in at least six cities, from downtown Frankfurt to small cities in Hesse's hinterland, considered starting BID projects as a means of promoting the development of city centres and solving the problems of property owners and retail enterprises. Some of these never got beyond initial discussions, while some came close to formally establishing a BID. In the following section, we discuss these cases. We argue that the success of BIDs is always dependent on the discursive constitution of an urban crisis that makes BIDs appear to be a promising solution to the crisis, and that even if such a broad crisis discourse exists, the strategies for overcoming crisis may be contested. 


\section{The absence of urban crisis}

Processes of reordering urban policies do not appear out of nowhere. Most BID initiation processes emerge from a specific discursive constitution of urban crisis that portrays BIDs as a perfect solution to that crisis. As we have argued elsewhere in more detail and in reference to Hamburg and Cape Town (Michel, 2013a; Michel and Stein, 2015: 82), BIDs are often closely linked to the articulation of eminent urban crises, which call for swift and bold action. The rise of BIDs in New York in the early 1990s and in Cape Town in the early 2000s was facilitated by a strong discourse on urban decay, crime and violence. Likewise, the introduction of BIDs in the United Kingdom in the early 2000s was part and parcel of New Labour's much wider discourse on urban renaissance.

While BIDs became powerful agents of urban revitalization in places that experienced a massive roll-back of public funding, the German context has seen less of a discourse of urban decline and urban crisis. In the absence of a discourse of imminent threat to the city and of BIDs as a crisis-solving strategy, the policy package tends not to receive strong support on the ground. Even in regional contexts that have been perceived as areas in crisis for decades (e.g. the post-industrial Ruhr Area, frequently seen as "Germany's rustbelt"), it is not the BID that comes to the rescue, even if local governments, chambers of commerce and some local business people rally for it. Such urban crises are framed in ways that do not make BIDs appear to be the natural solution. The absence of discourses of urban crises to which BIDs are the solution is due to specificities in the situation of urban retail in Germany and to the path-dependent development of a strong local state in Germany. We turn now to these reasons behind the absence of crisis.

\section{Failures to depict inner-city retail as threatened}

According to local business communities, competition with other retail sites (typically with suburban shopping centres) is an increasing threat. It is said to cause a severe loss of purchasing power. Such external threats are frequently used to legitimize BIDs. In our study, the threat of a newly built inner-city shopping centre was used to justify four BID initiatives in the city of Giessen. One BID defender interviewed for the project explained the situation thus:

Of course, we had the advantage that we could mobilize the local retailers through the establishment of the 'Galerie Neustädter Tor' [shopping centre]. That was for many in Giessen a concept of the enemy, it was like the 'Death Star', 'the Evil Empire'. (Interview 2011, BID Seltersweg Giessen, translation by the authors)

However, this legitimization turns out to be not appropriate in any case. As the example of another BID initiative in Wiesbaden shows:

...one does not automatically come up with the idea, that the 'Taunusstraße' of all things is in need of a BID. [...] I mean, if I am in Wiesbaden and getting to another place, I always think: Oh my God, this city is the island of bliss. (Interview 2011, City of Wiesbaden)

The case of Wiesbaden shows that, in order to push forward a BID project, an articulation of a crisis has to be accompanied by a prevalent sense that the crisis actually exists.

\section{Failure to blame freeriding for the deterioration of property owners' sense of place}

A further strategy for legitimizing BIDs is to frame inner-city areas as commons that have to be preserved as a historical place of local communities and protected from freeriders. According to this line of argumentations, freeriders pose a threat for the following reason:

...individual freedom thus degenerates into parasitism. The decreasing numbers of members of the local retail associations, which organize advertising, markets or Christmas illuminations rightly get the impression of getting ripped off by an increasing number of retail chain stores, not having a share in such campaigns. [...] Hence, from a regulative and a sociopolitical perspective one can highly appreciate INGE [Hessian BID] as attempt to avert freeriding. In times of growing individualization - that is the philosophy of INGE solidarity has to be helped along, to overcome 
neoliberal ideology. (Hausmann, 2010: 1, translated by the authors)

While co-opting critical perspectives on neoliberalism and individualism, in that way BID defenders try to position a discourse of solidarity to promote BID implementation.

However, the argument that tries to appeal to individual responsibilities has to be repeated again and again - a fact that shows that it is still contested. For example, this is the case in Wiesbaden, where there has been little success in holding local property owners responsible for their quarter. As a co-initiator of the BID initiative put it:

Hamburg is the only city in Germany that has real citizens. [...] But there are no citizens in Wiesbaden. Here are just people who use the city. [...] The commitment you need to get a BID going involves a certain attitude. And this attitude is missing in most cities in Germany. (Interview W1, 2011, Stadt Wiesbaden, translated by the authors; for more details on this case study, see Pütz et al., 2013)

Property owners' resistance to assuming responsibility draws upon the dominant ideas of a strong and caring (local) welfare state in Germany, to which our discussion now turns.

\section{Failure to constitute a crisis of the local state}

A third common way to legitimize BIDs is to diagnose a failure of the local state, which is attributed to the state's limited financial scope and inability (due to red tape) to organize urban renewal processes in a way that property owners approve of. While the massive roll-back of the state makes this a compelling argument in many countries, it is less plausible in others. Taking an example at the local state level, a BID initiative in one of Frankfurt's suburbs illustrates the trajectories of a welfare state that is still substantial and powerful. It is in the urban district of Frankfurt Höchst, where the massive intervention of the local state is a case in point against the state failure argument. At the outset, a BID initiative led to a 20 million euro funding program being launched by the city council in 2008; however, the BID eventually failed because strong public funding undermined the grounds for its existence and its legitimization (for more details on this case study, see Silomon-Pflug et al., 2013: 209f.). Moreover, even in discourses on BIDs at the federal state level, a number of advocates have voiced concerns that property owners are reluctant to engage with BIDs because they know that the federal state will take care of their needs in the end. This is the case for discussions of BIDs in NorthRhine Westphalia, a federal state with a strong corporatist and social-democratic tradition. All in all, property owners and local businesses in Germany quite often rely on the idea of a strong and caring local state and therefore see no need for the BID model.

\section{Failure to present Business Improvement Districts as a solution}

The failure to (re)embed mobile policies cannot be explained solely in terms of the failure to constitute specific urban crises. It is also related to the failure to promote a specific policy as the appropriate solution to the problem at hand.

BIDs in the USA tend to be extended easily and put into almost permanent frameworks. This enables long-term planning and investments that appear much more stable to property owners than state interventions that are subject to electoral shifts. A statement made by a BID advocate from Philadelphia demonstrates how important BIDs are considered in the USA in relation to municipal institutions. Irrespective of "a good mayor, a bad mayor, a good city council, a bad city council," he argues, "the BID is there, long-term, reflecting the interests of the city center" (Levy, 2010). In the German context, BIDs became more focused on single and simple issues, probably due to the statist fear of giving away too much regulatory power. Instead of long-term planning for urban renewal, they focus on things like seasonal lighting and above-standard road surfaces. Not only does BID legislation in Germany limit the term for BIDs to a maximum of five years, but BID legislation itself expires in some federal states, so the continuity of advocating private sector interests through BIDs is not secured beyond short-term projects. 
Thus, BIDs in Germany are confronted with precarious conditions. Moreover, even if BID legislation is in place indefinitely, many BIDs expire after their first term. As many BIDs perform limited tasks or pursue a single objective, BID advocates do not see a need to apply for a further term. For example, in the federal state of Schleswig-Holstein, three of four BIDs created between 2007 and 2012 expired without trying to expand their activities. Thus, in contrast to BIDs in the USA, many BIDs in Germany do not even claim to be crucial actors in local governance.

Limitations in the scale and scope of BIDs created by these temporal constraints are increased by the relatively limited economic capacities of BIDs in Germany. Dense Central Business Districts that can raise enormous levies due to their large floor spaces in high-rise office towers are the global flagships of "successful" BIDs; the average four- to five-storey buildings found in most German inner cities cannot raise this amount of financial capital.

Research on mobile policies has to stop conceptualizing policy transfer as the transfer of "the whole package" (Brenner et al., 2010: 214) and not just a shiny label. While BIDs are frequently evoked as appropriate tools for managing urban spaces in a closer and more focused way than a local state can (even in Germany), the legal context created by BID legislation in Germany and predominant patterns of urban morphology there significantly affect the ability of BIDs to fulfil this role.

\section{Fragile and contradictory neoliberal coalitions}

The literature on neoliberal urbanism suggests that BIDs are the natural ally of agents such as property owners, neoliberal politicians and local capital; however, our analysis of BIDs in Germany shows that the relationship between these actors is ambiguous. This is true from the perspective of both the state and private capital, and on a variety of scales. In the following, we draw on debates at the federal state level and discourses on the city and district level in order to map conflicting interests surrounding BIDs.

At the federal state level, the position of the Liberal Democratic Party (FDP) (the champions of a neoliberal agenda in Germany) exemplifies these contradictions. From a liberal perspective - as voiced, for example, by the FDP in the federal state of Baden-Württemberg - BIDs can be seen less an instrument in favour of the free market, and more as a hidden tax increase enforced by the state against the invisible hand of the market (see, e.g., FDP Mannheim, 2013). BIDs, it is argued, force property owners to join a place-based association even if it is against their individual will. This is one reason why the FDP often opposes BID legislation at both the local and the federal state level. Even in Bavaria and other federal states that were not governed by a leftist government, BID laws were rejected on the grounds of being against free market principles and for being in conflict with the constitutionally guaranteed negative freedom of association (Stoiber, 2003: 2). This line of argument is similar to ultraliberal stances on Homeowner Associations and BIDs in North America and sees BIDs less as a means of opening up the city for the free market and more as an essentially statist instrument.

Such frictions are most visible on the scale of the federal state, where BID laws are debated. Until 2013, BID laws were only put in place in federal states that were being run by conservative governments. In most cases, governments led by the Social Democrats (SPD) and The Left Party (Die Linke) voted against introducing BIDs. However, it would be misleading to see BIDs solely as a tool for conservative and neoliberal politics. In federal states governed by conservative parties that did not establish BID laws, more often than not the Social Democrats and The Greens were asking for their implementation. For The Greens in particular, BIDs seem closely aligned with the party's emphasis on civic participation and volunteerism. Hence, it is not an accident that The Greens in Hamburg, who are part of a coalition government with the Social Democrats, have been the principal supporters of amending the BID law since the conservatives were voted out of office.

Moreover, frictions are not limited to the realm of party-politics on the national or federal state level. As illustrated in the case of Giessen, local path dependencies and local stakeholders are, at times, much more important for the trajectories of specific BID initiatives than party lines at the national or federal 
state level. At the federal state level, traditional conservatives and centre-left parties are concerned that BIDs are hollowing out the state's capacity to govern. Hence, local and state administrations keep relying on conventional bureaucratic operations in an effort to preserve their traditional power over urban development. Institutional stickiness may not generate the far-reaching publicity effects that political conflicts do, but it is one of the main reasons why BIDs fail. BID development in the City of Frankfurt is a case in point. There, the city prevents private initiatives from gaining power through BIDs (which is seen as a quasi "sovereign" institutionalization of private interests), by preventing BIDs from having a say in matters related to the development of city districts (SilomonPflug et al., 2013).

Beyond federal states' claim to power over the trajectory of urban development, a more general argument is put forward against allowing private interests to influence the development of city districts. This argument challenges the basis of BID legitimation, by questioning their compliance with minimum democratic standards. The case of Wiesbaden serves to illustrate this point. There, powerful actors (mostly old-established trades and property owners) used this argument to organize resistance against the BID initiative. In this case, a lawyer pooled the interests of those opposing the BID and effectively blocked the initiative by threatening to make its democratic legitimation the subject of a legal contest. Faced with this threat, the BID initiative failed the quorum to become institutionalized. However, lobby groups on the side of property owners and business people do not have a coherent position towards BIDs. While many retail alliances and local chambers of commerce are often the strongest supporters of BIDs, the resistance of local property owners - those who directly pay the BID often remains strong. The national Association of Property Owners (Haus und Grund), for example, view BIDs as a socialist sanction and a "license to cash in on property owners" (Haus und Grund Germany, 2004; translated by the authors). BIDs are not seen as a vehicle for promoting free market principles and neoliberal urban governance, but as an agent of the state and a way of extracting more taxes from property owners.
Moreover, on a material level, the dynamics of BID initiatives depend on financial and other resources. For example, while emerging BIDs in Hamburg could rely on the existing personal networks of private and state institutions and highly specialized, financially well-positioned consultancies, BID initiatives in most other cities could not.

\section{Conclusion - follow the failure}

Taking the failure of policy mobilities seriously allows for a critical examination of the idea of a globalizing neoliberalism. In this paper, we argued for a much closer analysis of failures and resistances within what is often seen as a relatively homogenous - or at least unidirectional - tendency towards the globalization of neoliberal urbanism. BIDs in Germany are a good case in point. BIDs are frequently taken as a prime example of neoliberal modes of urban governance and as a prime example of a mobilized policy. The German case studies we drew on show not only that these transfers frequently fail, but also that there are a number of different social contexts in which constraints and resistances can and do occur. Starting from these empirical experiences with BIDs, we would argue that it may not meet the complexities of the processes involved in the (im-)mobilization of BID policies to frame them in a conceptual draft as "an iterative, three-step cycle of transportation-transformation-translation", as suggested by Müller (2015: 193f.). The success of BIDs in Germany varies strongly across the country; BID initiatives have failed on a variety of scales, due to a lack of support from federal state governments, dismissive city governments and opposing property owners in local city districts. While neoliberal politicians, property owners and retailers are often presumed to be part of alliances in favour of BIDs, conflicting stances held by these actors undermine the vigour of coalitions attempting to establish them. In addition, local constellations of institutions and individual actors, assembled through path-dependencies and endowed with specific power resources, influence local urban development trajectories in a crucial way.

Reflecting on failing transfers provides both a counterweight to the success bias within the literature on mobile policies and a strong means of arguing that 
"neoliberal urbanism" - if we want to cling to that term at all - is a complex and contradictory process that plays out in extremely different ways in places that are both discrete and interconnected at the same time: what appears to be a vital policy of neoliberalism in one place can be opposed by agents of neoliberalism in other places.

\section{Acknowledgements}

We would like to thank all discussants in the joint research project "Re-ordering the city in the age of Neoliberalism" for their intellectual inspiration and two diligent referees for their helpful remarks. Research for this paper was funded by the German Research Foundation (DFG).

\section{Notes}

1. As is the case in the USA and South Africa, the German federal system requires BID legislation to be passed at the federal state level. This led to a fragmented BID policy landscape. German law may not contain any non-German terminology. Therefore, the official nomenclature denoting BIDs differs in some states' laws. Hamburg's Law for Strengthening Retail, Service and Business Centres (Gesetz zur Stärkung der Einzelhandels-, Dienstleistungs- und Gewerbezentren - GSED, all translations by the authors) refers to BIDs as "areas for strengthening the innovation of retail, service or business centres" or "innovation areas". In Schleswig-Holstein they are referred to as "partnerships for improving city, service and tourism areas" (Partnerschaften zur Attraktivierung von City-, Dienstleistungs- und Tourismusbereichen PACT). In Saarland they are called "alliances for innovation and services" (Bündnisse für Investition und Dienstleistung - BID). Nonetheless, "Business Improvement District" remains the term most often used in public and political discourse.

2. The federal states of the former German Democratic Republic (GDR) represent a special case. Due to a lack of economic development and shrinking cities, development schemes to promote BIDs and establish highly subsidized pilot projects were initiated in 2005 and funded mainly by the national government. These pilot projects were eventually phased out and did not have much lasting effect (DIHK, 2012).

\section{References}

Allen J and Cochrane A (2007) Beyond the territorial fix: regional assemblages, politics and power. Regional Studies 41(9): 1161-1175.
Binger S (2010) Erfolgsfaktoren im Gründungsprozess von Business Improvement Districts. Ein Überblick über den Forschungsstand und eine empirische Analyse von Gründungsprozessen deutscher BID-Initiativen [Success Factors in the Process of Establishing Business Improvement Districts: An Overview of the Current State of Research and an Empirical Analysis of Foundation Processes of German BID Initiatives]. Hamburg: Kovac.

Bloem Mand Bock S (2001) Business Improvement Districts (BID). Untersuchung von Business Improvement Districts (BID) in Bezug auf Möglichkeiten und Grenzen einer Übertragbarkeit auf Innerstädtische Geschäftsquartiere in Nordrhein-Westfalen [Business Improvement Districts (BID). Analysis of Business Improvement Districts (BID) Related to Possibilities and Limits of Transferability to Inner-City Shopping Districts in Northrhine-Westphalia]. Düsseldorf: Department of State of Urban Development and Housing in North-Rhine Westphalia (MSWKS).

Brenner J (2010) Private initiatives in German urban development policy. Urban Research \& Practice 3(2): 219-228.

Brenner N, Peck J and Theodore N (2010) Variegated neoliberalization: geographies, modalities, pathways. Global Networks 10(2): 182-222.

Bundesvereinigung City- und Stadtmarketing e.V.(BCSD) (ed.) (2007) Business Improvement Districts. Vom 'Ob?' zum 'Wie?' [Business Improvement Districts. From 'If?' to 'How?']. Aachen: Shaker.

Carr C (2013) Discourse yes, implementation maybe: An immobility and paralysis of sustainable development policy. European Planning Studies 22(9): $1824-1840$.

Cochrane A and Ward K (2012) Researching the geographies of policy mobility: confronting the methodological challenges. Environment and Planning $A$ 44(1): 5-12.

Collier S and Ong A (2005) Global assemblage, anthropological problems. In: Ong A and Collier S (eds) Global Assemblage, Anthropological Problems. Malden, MA: Blackwell, 3-21.

Cook IR (2008) Mobilising urban policies: the policy transfer of US Business Improvement Districts to England and Wales. Urban Studies 45(4): 773-795.

Cook IR and Ward K (2012) Conferences, informational infrastructures and mobile policies: the process of getting Sweden 'BID ready'. European Urban and Regional Studies 19(2): 137-152.

Deutscher Industrie- und Handelskammertag (DIHK) (ed.) (2012) BIDs - eine erfolgreiche Form von Public Private Partnership zur Zentrenentwicklung. Übersicht 
der BID-Initiativen nach Bundesländern [BIDs - A Successful Form of Public Private Partnership for the Development of City Centres]. Available at: http:// www.dihk.de/ressourcen/downloads/bids-deutschland. pdf/at_download/file? mdate $=1339664201042$ (accessed 5 March 2014).

Didier S, Peyroux E and Morange M (2012) The spreading of the city improvement district model in Johannesburg and Cape Town: urban regeneration and the neoliberal agenda in South Africa. International Journal of Urban and Regional Research 36(5): 915-935.

Dolowitz D and Marsh D (1996) Who learns what from whom: a review of the policy transfer literature. Political Studies 44(2): 343-357.

Dolowitz D and Marsh D (2000) Learning from abroad: the role of policy transfer in contemporary policymaking. Governance 13(1): 5-24.

Eick V (2012) The co-production of purified space: hybrid policing in German Business Improvement Districts. European Urban and Regional Studies 19(2): 121-136.

Farías I and Bender T (eds) (2010) Urban Assemblages. How Actor-Network Theory Changes Urban Studies. London: Routledge.

FDP Mannheim (2013) Widerstand gegen InnenstadtGesetz: FDP lehnt Business Improvement Districts klar $a b$ [Resistance against Inner City Law: Liberal Democrats Clearly Refuse Business Improvement Districts]. Available at: http://fdp-ma.de/2013/06/10/ widerstand-gegen-innenstadt-gesetz-fdp-lehntbusiness-improvement-districts-klar-ab/ (accessed 8 December 2013).

Glasze G (2001) Privatisierung öffentlicher Räume? Einkaufszentren, Business Improvement Districts und geschlossene Wohnkomplexe [Privatizing public spaces? Shopping Malls, Business Improvement Districts and Gated Communities]. Berichte zur deutschen Landeskunde 75(2-3): 160-177.

Guggenheim M and Söderström O (eds) (2010) Re-Shaping Cities: How Global Mobility Transforms Architecture and Urban Form. London: Routledge.

Haus und Grund Germany (2004) "Lizenz zum Abkassieren der Grundeigentümer" ["License to cash in on property owners"]. Press release, 23.06.2004 Berlin. Available at: http://www.hausundgrund.de/ presse_265.html.

Hausmann B (2010) Stellungnahme zur öffentlichen Anhörung des Ausschusses für Wirtschaft und Verkehr zum Gesetzentwurf der Landesregierung für ein Gesetz zur Änderung des Gesetzes zur Stärkung von innerstädtischen Geschäftsquartieren (INGE) [Opinion on the public hearing of the committee for economy and transport concerning the state governments draft legislation for a law to change the law for strengthening inner city commercial districts (INGE)] Aktenzeichen: 18/2377, 26 August (Drucksache). Wiesbaden: Hessischer Landtag.

Hoyt L (2006) Importing ideas: the transnational transfer of urban revitalization policy. International Journal of Public Administration 29(1): 221-243.

Hoyt L (2008) From North America to Africa: the BID model and the role of policy entrepreneurs. In: Morçöl G, Hoyt L, Meek J and Zimmermann U (eds) Business Improvement Districts: Research, Theories, and Controversies. Philadelphia, PA: Taylor \& Francis, 111-131.

James O and Lodge M (2003) The limitations of "policy transfer" and "lesson drawing" for public policy research. Political Studies Review 1(2): 179-193.

Katz C (2001) Hiding the target: social reproduction in the privatized urban environment. In: Minca C (ed.) Postmodern Geography: Theory and Praxis. Oxford: Blackwell, 93-110.

Kelling G (2009) How New York became safe: the full story. Available at: http://www.city-journal. org/2009/nytom_ny-crime-decline.html (accessed 10 March 2014).

Köhler M (2010) Business Improvement Districts: eine zweite Chance für Inge. [Business Improvement Districts: a second chance for 'Inge']. Frankfurter Allgemeine Zeitung, 6 August. Available at: http:// www.faz.net/aktuell/rhein-main/region/businessimprovement-districts-eine-zweite-chance-fueringe-11025877.html

Künkel J (2015) Urban policy mobilities versus policy transfer. Potenziale für die Analyse der Neuordnung. sublurban 3(1): 7-24.

Levy P (2001) Paying for the public life. Economic Development Quarterly 15(2): 124-131.

Levy P (2010) BIDs and town centre management worldwide experiences. Talk presented on the 2nd BID-Bundeskongress, Bochum, 1 October.

McCann E (2008) Expertise, truth, and urban policy mobilities: Global circuits of knowledge in the development of Vancouver, Canada's 'four pillar' drug strategy. Environment and Planning A 40(4): 885-904.

McCann E (2011) Veritable inventions: cities, policies and assemblage. Area 43(2): 143-147.

McCann E and Ward K (2010) Relationality/territoriality: toward a conceptualization of cities in the world. Geoforum 41(2): 175-184.

McCann E and Ward K (eds) (2011) Mobile Urbanism: Cities and Policymaking in the Global Age. Minneapolis, MN: University of Minnesota Press. 
McCann E and Ward K (2012a) Assembling urbanism: following policies and 'studying through' the sites and situations of policy making. Environment and Planning A 44(1): 42-51.

McCann E and Ward K (2012b) Policy assemblages, mobilities and mutations: toward a multidisciplinary conversation. Political Studies Review 10(3): 325-332.

Mac Donald H (1996) BIDs really work. City Journal 6(2). Available at: http://www.city-journal.org/ html/6_2_a3.html (accessed 10 March 2014).

McFarlane C (2011) Learning the City: Knowledge and Translocal Assemblage. Chichester: WileyBlackwell.

McLean B and Borén T (2014) Barriers to implementing sustainability locally: a case study of policy immobilities. Local Environment. Epub ahead of print 23 April. DOI: 10.1080/13549839.2014.909798.

Michel B (2013a) A global solution to local urban crises? Comparing discourses on Business Improvement Districts in Cape Town and Hamburg. Urban Geography 34(7): 1011-1030.

Michel B (2013b) Wenn mobile Politiken gegen die Wand fahren. Grenzen des Politik Transfers am Beispiel von Business Improvement Districts in Deutschland [When mobile policies hit the wall. Limits of policy transfer using the example of Business Improvement Districts in Germany]. Berichte zur deutschen Landeskunde 87(1): 87-102.

Michel B and Stein C (2015) Reclaiming the European city and lobbying for privilege: Business Improvement Districts in Germany. Urban Affairs Review 51(1): 74-98.

Ministerium für Arbeit, Soziales und Stadtentwicklung, Kultur und Sport des Landes Nordrhein-Westfalen (MASSKS) [Department of State NorthrhineWestfalia for Labour, Social Affairs and Urban Development, Culture and Sports] (ed.) (1999) Stadtplanung als Deal? Urban Entertainment Center und private Stadtplanung. Beispiele aus den USA und Nordrhein-Westfalen [Urban planning as deal? Urban Entertainment Centres and Private Urban Planning. Examples from the USA and Northrhine-Westfalia]. Düsseldorf: Toennes.

Müller M (2015) (Im-)Mobile policies. Why sustainability went wrong in the 2014 Olympics in Sochi. European Urban and Regional Studies 22(2): 191-209.

Peck J (2011) Geographies of policy: from transfer-diffusion to mobility-mutation. Progress in Human Geography 35(6): 773-797.

Peck J and Theodore N (2001) Exporting workfare/ importing welfare-to-work: exploring the politics of third way policy transfer. Political Geography 20(4): 427-460.

Peck J and Theodore N (2010) Mobilizing policy: models, methods, and mutations. Geoforum 41(2): 169-174.

Peck J and Theodore N (2012) Follow the policy: a distended case approach. Environment and Planning $A$ 44(1): 21-30.

Perrons D and Posocco S (2009) Globalising failures. Geoforum 40(2): 131-135.

Peyroux E, Pütz R and Glasze G (2012) Business Improvement Districts (BIDs): internationalisation and contextualisation of a "travelling concept." European Urban and Regional Studies 19(2): 111-120.

Prince R (2010) Policy transfer as policy assemblage: making policy for the creative industries in New Zealand. Environment and Planning A 42(1): 169-186.

Pütz R (2012) Business Improvement District. In: Marquardt N and Schreiber V (eds) Ortsregister. Bielefeld: transcript, 50-56.

Pütz R and Rodatz M (2013) Kommunale Integrationsund Vielfaltskonzepte im Neoliberalismus. Zur strategischen Steuerung von Integration in deutschen Großstädten. Geographische Zeitschrift 101(3-4): 166-183.

Pütz R, Stein C, Michel B and Glasze G (2013) Business Improvement Districts in Deutschland Kontextualisierung einer "mobile policy" [Business Improvement Districts in Germany - contextualization of a "mobile policy"]. Geographische Zeitschrift 101(2): 82-100.

Robinson J (2006) Ordinary Cities: Between Modernity and Development. London: Routledge.

Robinson J (2011) The spaces of circulating knowledge: city strategies and global urban governmentality. In: McCann E and Ward K (eds) Mobile Urbanism: Cities and Policymaking in the Global Age. Minneapolis, $\mathrm{MN}$ : University of Minnesota Press, 15-40.

Rothmann D (2008) Die Hansestadt Hamburg und das Hamburger BID-Gesetz. Pilotprojekt "Neuer Wall" - Standortaufwertung durch Eigeninitiative, ein Zwischenbericht [The Hanseatic City of Hamburg and the Hamburgian BID law. Pilot project 'Neuer Wall' - improving locations through proactivity, a preliminary report.]. In: Pechlaner $\mathrm{H}$ and Zehrer A (eds) Business Improvement Districts (BID). Grundlagen Konzepte - Perspektiven. Wien: Linde, 93-108.

Roy A (2012) Ethnographic circulations: space - time relations in the worlds of poverty management. Environment and Planning A 44(1): 31-41.

Säfke I (2007) BID-Kongress Gießen. In: Deutscher Industrie- und Handelskammertag (DIHK) (ed.) BID News (02). Berlin. 
Schwedes C (2012) Contingent stories of success: Business Improvement Districts assembled in Germany. Paper presented to the Annual Association of American Geographers meeting, New York, 28 February.

Shore C and Wright S (1997) Anthropology of Policy: Critical Perspectives on Governance and Power. London and New York: Routledge.

Silomon-Pflug S, Stein C, Pütz R and Heeg S (2013) Die unternehmerische Stadt als Gegenstand von UrbanPolicy-Mobilities-Forschung. Kontextualisierung global verfügbarer Politikmodelle am Beispiel BID und PPP in Frankfurt am Main [Urban policy mobility studies and the entrepreneurial city: contextualizing BID and PPP as globalized policy models in Frankfurt, Main]. Geographische Zeitschrift 101(34): 201-217.

Smith N (1996) The New Urban Frontier: Gentrification and the Revanchist City. London and New York: Routledge.

Stoiber E (2003) Antwortschreiben von Ministerpräsident Stoiber vom 22. Oktober 2003 mit Stellungnahme zum Antrag der Stadt Augsburg für die Einrichtung von BIDs in Bayern [Written Reply of the Secretary of State of Bavaria, Stoiber, of October 22, 2003 with Statement to the Proposal of the City of Augsburg for the Establishment of BIDs in Bavaria]. Munich: Der Bayerische Ministerpräsident.

Ward K (2006) "Policies in motion", urban management and state restructuring: the trans-local expansion of business improvement districts. International Journal of Urban and Regional Research 30(1): $54-75$.

Ward K (2007) Business Improvement Districts: policy origins, mobile policies, and urban liveability. Geography Compass 1(3): 657-672.

Wedel JR, Shore C, Feldman G and Lathrop S (2005) Toward an anthropology of public policy. Annals of the American Academy of Political and Social Science 600(1): 30-51.

Wolman H (1992) Understanding cross national policy transfers: The case of Britain and the US. Governance 5(1): $27-45$. 